\title{
ÇALIŞANLARDA ADALET VE YÖNETICİ DESTEĞİ ALGISININ GÜVEN OLUŞUMUNDAKİ ROLÜ: HAVACILIK SEKTÖRÜNDE BİR UYGULAMA
}

\author{
THE ROLE OF PERCIEVED JUSTICE AND SUPERVISOR SUPPORT ON TRUST AMONG \\ EMPLOYEES: AN APPLICATION ON AVIATION SECTOR
}

Cenk AKSOY ${ }^{1}$

Özet

Bu çalışmada, örgütlerde çalışanların örgütsel adalet ve yönetici desteği algısının, örgütsel güven algısı üzerindeki etkis in in araştırılması a maçlanmıştır. Modeli test etmek a macıy la demografik değ iş kenler dışında 16 soruluk bir anket kullanılmıştır. Bu anketler Türkiye'nin Güneydoğu bölgesi illerinde havacılık sektöründe çalışan personele dağıtılmış ve analiz için 447 anket kullanılmıştır. Araştırmada elde edilen veriler, araştırmanın amac1 doğrultusunda çeşitli istatistik metot ve test teknikleri (frekans dağılımı, t-testi, Anova, regresyon, korelasyon) kullanılarak SPSS 18.0 istatistik paket programı yardımıy la değerlendirilmiştir. Anlamlılık düzeyi 0.05 olarak kabul ed ilmiştir. Araştırmada çalışanların örgütsel adalet ve yönetici desteği algıs ın ın, örgü ts el güven algısı üzerinde pozit if ve anlamlı bir etkisinin olduğu sonucuna ulaşılmıştır. Ayrıca çalışan algılarının bazı demografik değişkenlere göre farklılaştığı tespit edilmiştir.

Anahtar Kelimeler: Yönetici Desteği, Örgütsel Adalet, Örgütsel Güven ve Havac1lık Sektörü

\begin{abstract}
This study aims to investigate the effect of organizational justice and supervisor support on organizational trust. A 16-items questionnaire except demographic questions was used to test the model. The survey was delivered to aviation sector employees in the Southeastern Anatolia Region of Turkey and a total of 447 completed questionnaires were used for analysis. The data obtained in the study were analy zed with SPSS 18.0 statistical software packages by using various statistical methods and testing techniques (frequency distribution, t-test, regression and correlation) for the purpose of research. It was found that there was a positive and significant effect of organizational justice and supervisor support on organizational trust. It has also been found that the latents were differs by some demographic variables of employees.
\end{abstract}

Keywords: Supervis or Support, Organizational Justice, Organizational Trust and Aviation Sector

${ }^{1}$ Arş. Gör. Dr., Dicle Üniversitesi SHYO, Sivil Hava Ulaştırma İşletmeciliği Bölümü, cenk.aksoy@dicle.edu.tr 


\section{Giriş}

Örgütsel anlamda adalet ve güven kavramları son yıllarda kullanılan anahtar kavramlardan olup, örgüt verimliliğine olan katkıları bilim dünyasında kabul görmektedir. Kavramların örgütsel faaliyetlerin etkililiğine olan faydası görüldükçe daha fazla kullanılmaya başlandığı görülmüştür.

Yönetici desteği kavramı ise literatürde adalet ve güven kavramlarına göre daha yeni araştırmalara konu olan bir kavram olarak gö ze çarpmaktadır. Bu kavramla ilg ili yapılan tanımlamalar sınırlı olmakla birlikte, bu tanımlara daha çok örgütsel destek kavramı içerisinde yapılan değerlendirmelerde rastlanılmıştır. Kısıtlı olarak genellikle örgütsel desteğin alt bir değişkeni olarak ifade edilen yönetici desteği kavramının başlı başına bir değişken olarak daha kapsamlı incelenmesi gerekliliğ i ortaya çıkmıştır. Bu kapsamda çalış mada yönetici desteği ka vramı ele alınarak tartışılmış ve diğer bazı örgütseldavranış konularıyla olan iliş kisi araştırılmıştır.

Adalet, güven ve yönetici desteği kavramlarının birlikte ele alındığ 1 bu ça lış manın örgütsel davranış literatürüne katk1 sağlayacağ1 düşünülmektedir.

Ayrıca örgütsel davranış alanında havacılık sektörüyle ilg ili yapılmış çalış malara diğer sektörlere n ispeten daha az rastlanmıştır. Yönetici desteği, örgütsel adalet ve örgütsel güven kavramları farklı alanlarda, farklı kombinasyonlarla incelenmesine rağmen, bu üç kavramın birlikte incelenmesine ayrıca kavramların havacılık sektöründe uygulanmasına pek rastlanmamıştır. Çalış ma, havacılık sektörünün yoğun çalışma ortamına sahip olması ve araştırmaya konu olan kavramların bu sektörde henüz yeterince araştırılmaması nedeniyle gerekli görülmüştür.

Çalışmada öncelikle örgütsel adalet, yönetici desteği ve örgütsel güven kavramları literatür özetlerine yer verilmiştir. Daha sonra ise alan araştırması kapsamında; bu kavramlar arasındaki ilişki havacılık sektöründe incelenerek geliştirilmesi gerekli görülen fonksiyonlara ilişkin çıktılara ulaşılması amaç lanmıştır. Elde edilen verilerin özellikle havacılık sektöründeki yönetici, çalışan ve akademisyenlere faydalı olacağı düşünülmüştür. Bu çalışmanın araştırma sorusu şu şekildedir: Çalışanların adalet ve yönetici desteği algılarının, örgütsel güven düzeyleri üzerinde etkisi var mıdır?

\section{Literatür Özeti \\ Örgüts el Adalet}

Bütün sosyal ortamlarda varlı̆̆ı çok önemli olan adalet kavramının örgütlerde ihmal edilmesi düşünülemez. Ancak adaletin örgütlerde dikkat edilen bir kavram olarak araştırılması hukuk ve sosyal bilimler alanlarında araştırılmasına göre nispeten daha yeni bir konudur(Çakmak, 2005: 19).

1960-1970'lerden beri iş ortamında dikkat edilen, önem verilen bir konu olarak adaleti açıklama ve tanımlama çabaları örgütsel adalet adı verilen yeni bir literatürün gelişmesine yol açmıştır (Greenberg, 1990: 400).

Örgütsel adalet, ö rgütsel kaynakların (ödül ve cezalar) dağıtımın ın, bu dağıtım kararlarını belirlemede ku llanılan prosedürlerin ve bu prosedürlerin yürütülmesi sırasında gerçekleşen kişiler arası davranışların nasıl olması gerektiği ile ilg ili kurallar ve sosyal normlar bütünü olarak izah ed ilmektedir (Folger ve Cropanzono, 1998: 110111).

Günümüzde yoğunlaşan rekabet nedeniyle örgütlerin ayakta kalabilmeleri çalışanlarından istedikleri verimliliği elde etmelerine bağlıdır. Örgütlerin çalışanlarından istedikleri verimliliğ i elde etmeleri ise çalışanlarının iş tatmin, motivasyon, performans düzeylerine bağlıdır. Tüm bu unsurları etkilediği düşünülen örgütsel adalet kavramı, çalışanların örgütleri hakkındaki düşüncelerini ve bu düşünceleri doğrultusunda örgütlerine karşı nasıl bir tutum ve davranış içine gireceklerini belirlemede çok önemli bir konudur (Cohen-Charash ve Spector, 2001: 278-279).

Buna göre çalışanların örgütlerini adil bulmamaları durumunda, verimliliklerini etkileyen önemli birer unsur olan iş tatmini, motivasyon ve performans düzeylerinde de bir düşüş yaşadıkları gö zlen miştir. Ayrıca çalışanların devamsızlıkların ın, işten ayrılma niyetlerinin arttığı görülmüş ve örgütlerde yaşanan stres ve gerginliğin en üst seviyeye ulaştığı belirlenmiştir (Schminke ve ark., 2000: 294; Çakmak, 2005: 21).

Örgütsel adalet kavramı araştırıldığ ında, literatürde genel anlamda üç temel boyutta incelendiği görülmektedir. Boyutlardan ilki dağıtım adaleti, ikincisi prosedür adaleti ve üçüncüsü de etkileşim adaletidir. Dağıtım adaleti çalışanın edindiği kazanımlar ve dağıtımlarla ilgiliyken, prosedür adaleti daha çok dağıtım kararlarının alınmasında kullanılan prosedürlere yöneliktir. Üçüncü boyut olan etkileşim adaletinde ise, çalışanlar arası ilişskilerin niteliği ön plandadır (Aktaş, 2010: 80). 


\section{Yönetici Desteği}

Yönetici desteği ile ilgili yapılan çalış malar oldukça yenidir. Bu kavramın örgütsel davranış literatüründe baş lı başına bir değişken olarak anılmaktan daha çok örgütsel desteğin alt bir değişkeni olarak incelendiği görülmüştür.

Yönetici desteği çalışanların ilk kademedeki yöneticilerinden gördükleri destek olarak ifade edil mektedir (Yoon ve Lim, 1999). Tanım olarak yönetici desteği; çalışanların, yöneticilerin kendilerini destekleyeceği ve cesaretlendireceği ve yöneticilerin kendilerini önemsiyor olduğu algısıdır (Burke, Borucki ve Hurley, 1992). Başka bir ifadeye göre yöneticinin çalışanına yönelik örgütsel anlamda destek vermesi ve yönetici ile çalışanı arasındaki olumlu iş ilişkisi yönetici desteği olarak ifade edilmiştir (Bhanthumnavin, 2003). Powell'a (2011) göre yönetici desteği, yöneticilerin personelinin katkılarını gözlemlemesi ve onların iyiliğ ini önemsiyor olmasıdır. Bir başka tanıma göre ise yönetici desteği çalışanların teşvik edilmesi, on lara destek olunması ve sorunları ile ilgilenilmesidir (Babin ve Boles, 1996).

Literatürdeki tanımlar genel olarak değerlendirildiğinde yönetici desteğini, çalışanlar ve yöneticiler arasındaki etkileşim düzeyin in belirlenmesinde çalışanların algıları açısından yöneticilerinden işlerle ilgili her konuda yardım ve destekalma düzeyi olarak ifade edebiliriz.

Yönetici desteği; üstleri tarafından saygın ve değerli olmak, yaptıkları ile üstleri tarafından takdir edilmek isteyen personel için çok önemli bir unsurdur. İnsanlar davranışlarını çevresine ve çevresindekilere göre oluşturur ve geliştirir. Bu gerçekten hareketle, personel gözünde bir yönetici organizasyonu temsil eder ve onun gözünde yönetici tarafindan desteklenmek organizasyon tarafindan desteklenmek anlamına gelir (Tongur, 2011). Bhanthumnavin (2000) tek boyutlu olarak ele alınan yönetici desteğinin, bilgisel, maddi ve duygus al olmak üzere üç boyuttan oluştuğunu ileri sürmüştür. Yönetici desteğinin bilgisel boyutu, işle ilgili mevzulara odaklanıldığ 1 boyuttur ve çalışanların verimliliğini artırmak maksadıyla gerekli olan ödül, ceza, geribildirim, bilgi ve beceriler şeklinde tanımlanmaktadır. Yönetici desteğinin maddi boyutunu ise çalışanların a maçlarına ulaşmalarında gerekli olan malzeme, teçhizat, zaman, servis hizmetleri, finans ve insan kaynağı oluşturmaktadır. Yönetici desteğinin son boyutu olan duygusal boyutu ise çalışanlara değer verme, ilgi, sevgi ve sayg1 gösterme, onlara güçlüklerle, stresle başa çıkmada ve çatışma çözme konusunda yardım ederek destek gösterme ola rak izah edilmektedir. Benzer bir araştırmada da önemli olduğu düşünülen yönetici desteği öğeleri arasında güven, sayg1 ve yöneticinin çalışanına yardım etme hususundaki çabasının olduğu belirtilmiştir (Gagnon ve Michael, 2004, akt. Giray, 2013).

\section{Örgüts el Güven}

Örgütsel güven, otuz yılı aşkın bir süredir yönetim biliminde araştırma konusudur (Wahlstrom ve Louis, 2008: 458). Örgütsel güven Tan ve Lim (2009: 45) tarafından örgüt çalışanlarının örgütün eylemlerine karş1 savunmasız kalmaya istekli olmaları olarak tanımlanmıştır. Yılmaz ve Atalay (2009: 341) ise kavramı örgütte çalışan herkesin hissettiği güven ve destek olarak açıklamıştır. Örgütsel güven kavramı ile ilgili yapılan diğer tanımlarda örgütsel güven (Polat, 2007: 46):

- Örgüt üyelerin in iyiliği için karşılıklı saygıya ve nezakete dayalı uyumlu davranışların bir sonucu olarak kazanılan bir olgudur(Taylor, 1989).

- Yöneticilerin verdikleri sözün arkasında duracaklarına dair çalışanların besledikleri inançtır (Mishra ve Morris sey, 1990).

- Örgütteki kişiler arası güvenin örgüte genelleştirilmesi ve başka bir deyişle, örgüte olan toplu yönelimi ifade eder (Zaheer ve ark., 1998).

Örgütsel güven, örgüt içinde güven temeline dayanan ilişkilerin kurulabilmesi, amaç lara u laşmada ve etkili bir ekip kurmada oldukça önemli bir unsurdur. Güvenin tam olarak yerleşmediğ i örgüt ortamlarında ise etkili ekiplerin kurulabilmesi, takım çalışmaların ın gerçekleştirilebilmesi ve belirlenen hedeflere ulaşılabilmesi oldukça güçtür(Asunakutlu, 2001: 5).

Örgüt içinde güven ortamının oluşması, astlar ve üstler arasında güvene dayalı ilişkilerin kurulması örgütsel performans1, üretken liğ i ve örgütsel bağl1lı̆̆1 etkilemektedir (Straiter, 2005: 86). Örgüt içerisinde güvene dayalı ilişkilerin oluşturulmas1 ve astların üstlerine ve bir bütün olarak örgütlerine güven hissetmelerin in, örgütlerine karşı duygusal açıdan bağımlı, kendilerini örgütlerinin bir parçası görebilen, işlerinden tatminkâr olabilen ve örgütlerinden ayrılmayı düşünmeyen çalışanlar oluşturabilir. Bu pozitif neticelerin görülebilmesi için çalışanların yöneticilerine ve örgütlerine karşı güven hissetmelerinde önemli olan unsurların ve güveni oluşturan etmenlerin ortaya çıkarılması gerekir (Demircan ve Ceylan, 2003:139). 
Örgütsel güven kavramı araştırıldığında, literatürde genel olarak üç temel boyutta incelendiği görülmektedir. Bu boyutlar; örgüte güven, yöneticiye güven ve çalışanlar arası güven olarak ortaya çıkmaktadır (Molla, 2011: 58).

\section{Yönetici Desteği, Örgütsel Adalet ve Örgütsel Güven Arasındaki İlişki}

Örgütler, hedeflerine ulaşabilmek için insan kaynağına büyük önem vermek durumundadır. Bir değer olarak gördügü çalışanlarına sürekli yatırım yapmak ve yatırım yaptığ 1 bu çalışanların örgütte kalmalarını sağlayarak etkinliklerini arttırmak için örgütlerine duydukları güven düzeylerini arttırmak zorundadır. Çalışanların, örgütlerine güvenebilmeleri adına örgütlerine duydukları adalet algısı ve yöneticilerinden aldıkları destek çok önemlidir. Adil bir çalış ma orta mında çalışanlar daha verimli ve performanslı olarak çalışabilecek bu da örgütün karlılığın 1 arttırmasına vesile o lacaktır. Örgütüne güvenen çalışanların oluşumunda ise belki de en temel yapıtaş 1 olabilecek kavram adalet algısı olarak karşımıza çıkmaktadır. Gerek örgütsel anlamda gerekse yöneticiler tarafından hassasiyetle yapılan adil uygulamaların olduğu bir örgütte çalışanların motivasyonları artmakta, haksız uygulamalarla karşılaşan çalışanların ise örgütlerine duydukları güven azaltmaktadır. Adalet duygusu zedelenen, yönetici desteğinden mahrum çalışanların örgüte olan güvenleri zayıflamakta, bu durum da çalışanların örgütlerinden ayrılmalarına, devamsızlık yapmasına ya da performanslarının düşmesine sebep olabilmektedir.

Buradan hareketle araştırmanın hipotezlerini şu şekilde geliştirebiliriz;

$\mathbf{H}_{1}$ : Örgütlerde çalışanların örgütsel adalet, yönetici desteği ve örgütsel güven algıları a rasında pozit if bir ilişkisi vardir.

$\mathbf{H}_{2}$ : Örgütsel adalet ve yönetici desteğinin, örgüts el güven üzerinde etkisi vardır.

Yapılan birçok çalışmada a lgılanan yönetici desteğinin, örgütsel adalet ve yöneticiye güven (örgütsel güvenin alt boyutu) arasında aracı etkisinin olduğuna ilişkin deneysel kanıtlar görülmüştür (DeConinck 2010; Aryee, Budhwar ve Chen 2002; St inglhamber, De Cremer ve Mercken, 2006; Frazier ve diğ., 2010; Zaitouni ve Nassar, 2015: 182).

Çalı̧anlar, yöneticilerin in yönetim yetkilerini ve kendi performansların ın değerlendirilmesi konusunda söz sahibi olduklarını bildiğinden yöneticilerini örgütün bir temsilcisi olarak görmektedir. Dolayısıy la yöneticiler tarafından yapılan pozit if ya da negatif tutum ve davranışlar çalışanlarda örgütsel güven gibi birtakım örgütsel düzeydeki kavramlara etki edebilmektedir.

$\mathrm{Bu}$ kapsamda incelenen kavramların hipotezlerle test edilmek üzere tüm değişkenlerin birlikte ele alınabi leceği bir hipotez modeli oluşturulmuştur. Literatürden yararlanarak geliştirilen kavramlar arasında doğrusal ilişkiyi gösteren model Şekil 1.'de verilmiştir.

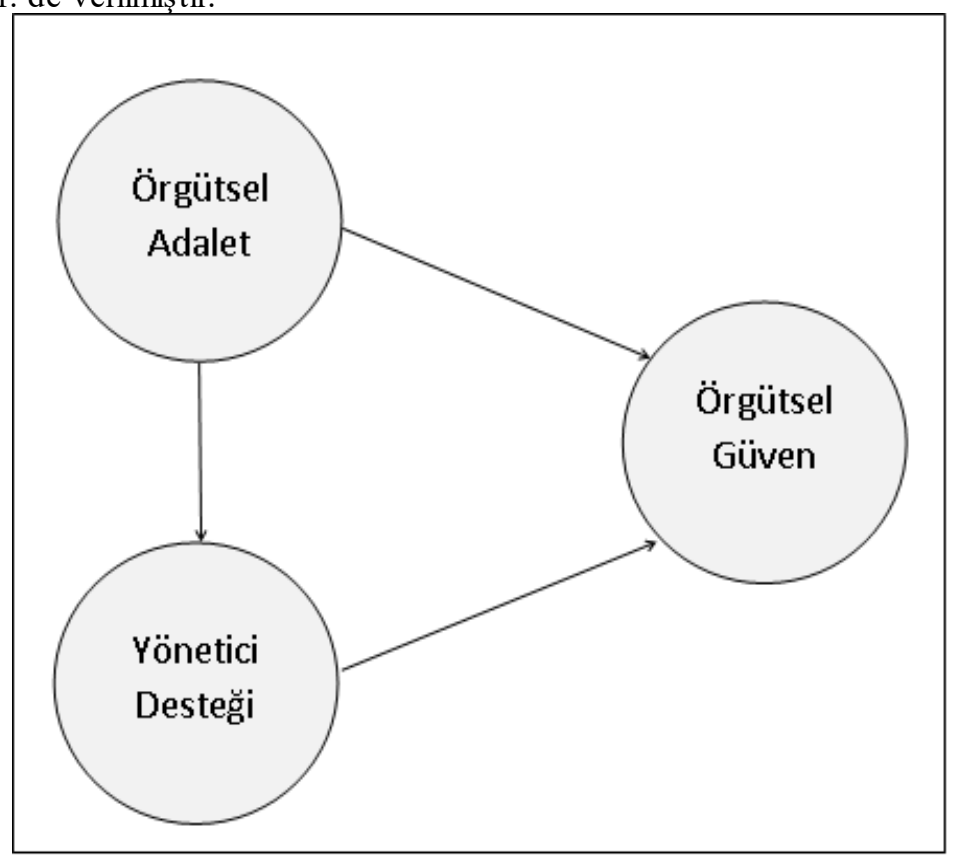

Şekil 1. Araştırmanın Modeli 


\section{Araştırmanın Yöntemi}

Araştırmanın Evreni ve Örneklemi: Hipotezleri ve modeli test etmek amacıyla demografik değişkenler dışında 16 soruluk bir anket kullanılmıştır. Bu ölçekler, Türkiye'n in Güneydoğu illerinde faaliyet gösteren havacılık iş letmeleri çalışanlarına rastgele dağıtılmış olup, analizler için toplamda 447 ölçek kullanılmıştır.

Veri Toplama Araçları: Verilerin toplanmasında; demografik bilgiler formu, örgütsel adalet, yönetici desteği ve örgütsel güven ölçeklerinden faydalanılmıştır. Ölçeklerin güvenilirlik analizleri yapılmış olup, yüksek düzeyde olduğu tespit edilmiştir. Çarpıklık ve basıklık değerleri -2 ve +2 arasında bulun muş olup, dağılımları normaldir.

Anket formunda yer alan ifadelere katılımcıların ne derecede katıldığın 1 belirlemek için 5'li Likert ölçeği kullanılmıştır. Buna göre ifadeler, "Kesinlikle Katılmıyorum (1)", "Katılmıyorum (2)", "Kıs men Katılıyorum (3)", "Katılıyorum (4)", "Tamamen Katılıyorum (5)" olarak sıralandırılmıştır.

a) Demografik Bilgiler Formu: Örgüt çalışanlarına ait demografik bilg ileri toplamaya yönelik olan bu ankette; yaş, cinsiyet, öğrenim durumu, medeni durum ve iş tecrübesi gibi özellikler yer almaktadır.

b) Örgütsel Adalet: Bu ö lçek çalışanların adalet algı dü zeylerini ölçmek için Niehoff ve Moorman (1993: 541) tarafindan geliştirilmiştir (Fields, 2002; 171). Türkçe'ye uyarlanan 5 soruluk bu ölçek için yapılan güvenilirlik analizinde Cronbach Alpha katsayısı 0.81 olarak bulunmuştur.

b) Yönetici Desteği: Bu ölçek çalışanların yönetici desteği alg 1 düzey lerini ölçmek için Oldham ve Cummings (1996: 634) tara findan geliştirilmiştir (Fields, 2002; 106). Türkçe'ye uyarlanan 7 soruluk bu ölçek için yapılan güvenilirlik analizinde Cronbach Alpha katsayısı 0.85 olarak bulunmuştur.

c) Örgütsel Güven: Örgütsel güvenin ölçülmesinde Nyhan ve Marlowe (1997) tarafından hazırlanan ölçek kullanılmıştır. Türkçe'ye uyarlanan 4 soruluk ölçeğin ifadelerinde düzeltmelere gidilmiştir. Yapılan güvenilirlik analizinde Cronbach Alpha katsayıs1 0.84 olarak bulunmuştur.

Verilerin Analizi: Verilerin değerlendirilmesinde SPSS 18.0 istatistik programı kullanılmıştır. Elde edilen verilerin analizinde t-testi, korelasyon ve regresyon testleri kullanılmıştır. Verilerin değerlendirilmesi, katılımcıların her bir soruya verdikleri cevapların toplam puanları üzerinden yapılmıştır. İstatistiki anlamlılık düzeyi $\mathrm{p}<0.05$ olarak kabul edilmiştir.

\section{Bulgular}

Araştırma hipotezlerini test etmek için korelasyon ve regresyon analizi kullanılmıştır. Araştır maya katılan kişilere ait bilgiler ilerleyen tablolarda gösterilmiştir. $\mathrm{Bu}$ tabloda görüldüğü gibi, havacılık işletmeleri çalışanlarından araştırmaya 447 kişi katılmıştır.

Tablo 1. Demografik Değişkenler

\begin{tabular}{|c|c|c|c|c|c|}
\hline Değişkenler & Frekans & $\begin{array}{l}\text { Yüzde } \\
(\%)\end{array}$ & Değişkenler & Frekans & Yüzde $(\%)$ \\
\hline \multicolumn{3}{|l|}{ Cinsiyet } & \multicolumn{3}{|l|}{ Eğitim Durumu } \\
\hline Erkek & 283 & 63,3 & İlköğretim & 74 & 16,6 \\
\hline Kadın & 164 & 36,7 & Lise & 143 & 32 \\
\hline \multirow{2}{*}{\multicolumn{3}{|c|}{ Yaş }} & Önlis ans-Lis ans & 220 & 49,2 \\
\hline & & & Lisansüstü & 10 & 2,2 \\
\hline $20-30$ & 177 & 39,6 & \multicolumn{3}{|l|}{ İş Tecrübesi } \\
\hline $31-40$ & 208 & 46,5 & 5 y1l ve alt1 & 146 & 29,5 \\
\hline $41-50$ & 54 & 12,1 & $6-10$ y1l & 132 & 15,9 \\
\hline 51 ve üzeri & 8 & 1,8 & $11-15$ y1l & 71 & 24,6 \\
\hline \multirow{2}{*}{\multicolumn{3}{|c|}{ Medeni Durumu }} & $16-20$ yil & 63 & 14,1 \\
\hline & & & 21 y1l ve üzeri & 35 & 7,8 \\
\hline Evli & 300 & 67,1 & \multirow{2}{*}{ Toplam } & \multirow{2}{*}{447} & \multirow{2}{*}{100} \\
\hline Bekâr & 147 & 32,9 & & & \\
\hline
\end{tabular}

Araştırmaya katılan havacılık sektörü çalışanlarının yaş gruplarına göre dağılımları incelendiğinde, çalışanların $\%$ 46,5' inin (208 kişi) 31-40 yaş aralığ ında, \%39,6'sının (177 kişi) 20-30 yaş aralığında, \% 12,1'in in (54 kişi) 41-50 yaş aralığında yer alırken \% 1,8'in in (8 kişi) de 50 yaş ve üstü yaşlarda olduğu; cinsiyet durumlarına göre dağılımları incelendiğinde, çalışanların \% 63,3'ünün (283 kişi) erkek, \% 36,7’sinin (164 kişi) bayan olduğu; medeni durumlarına göre dağılımları incelendiğinde, çalışanların \% 67,1'inin (300 kişi) evli, \% 32,9'unun (147 kişi) bekâr olduğu; eğitim durumlarına göre dağılımları incelendiğinde, çalışanların \% 49,2'sinin (220 kişi) 
önlisans-lisans, \% 32'sinin (143 kişi) lise, \% 16,6'sının (74 kişi) ilköğretim, \% 2,2'sin in (10 kişi) de lisansüstü mezunu olduğu; iş tecrübelerine göre dağılımları incelendiğinde, çalışanların \% 32,7'sinin (146 kişi) 1-5 yıl aras1, \%29,5' inin (132 kişi) 6-10 y 1l arası, \% 15,9'unun (71 kişi) 11-15 yıl arası, \% 14,1'inin (63 kişi) 16-20 yı1 arası ve \% 7,8'inin (35 kişi) 20 ve üzeri yıl iş tecrübesiolduğu Tablo 1.'de gösterilmiştir.

Araştırmaya konu olan kavramlar arasında is tatistiksel bir iliş ki olup olmadığın 1 araştırmak amacıy la kore lasyon analizi yapılmıştır.

Tablo 2. Adalet, Yönetici Desteği ve Güven Arasındaki İlişki

\begin{tabular}{|c|c|c|c|c|}
\hline & & 1 & 2 & 3 \\
\hline 1. Örgütsel Adalet & \multirow{3}{*}{$\begin{array}{l}\text { Correlation } \\
\text { Coefficient }\end{array}$} & 1 & $0,820 * *$ & $0,759 * *$ \\
\hline 2. Yönetici Desteği & & & 1 & $0,858 * *$ \\
\hline 3. Örgütsel Güven & & & & 1 \\
\hline
\end{tabular}

Tablo 2'de katılımcılara ait örgütsel adalet ile yönetici desteği ilişkisi \% 82 olarak, örgütsel adalet ile örgütsel güven ilişkisi \% 75,9 olarak, yönetici desteği ile örgütsel güven ilişkisi \% 85,8 o larak olarak tespit edilmiştir. Bu tabloda görüldüğ̈̈ gibi, örgütsel adalet, yönetici desteği ve örgütsel güven arasında güçlü pozitif bir doğrusal ilişki mevcuttur $(\mathrm{p}<0.001)$. Dolayısıyla araştırmanın birinci hipotezi $\left(\mathrm{H}_{1}\right)$ kabul edilmiştir.

Çalış mada incelenen değişkenlerin ara larındaki korelasyon katsayıları incelendiğinde, değişkenler a rasındaki en büyük korelasyon katsayısının 0.858 ile güven alg 1sı ve yönetici desteği algısı değişkenleri arasında olduğu da görülmektedir. Çalışanlar açısından yöneticilerin kendilerine ne kadar destek verdiği, aynı zamanda onların yöneticilerine ne kadar güven duyduklarıyla yakından iliş kilidir.

Araştırma modeli kapsamında bağımlı değişkenin, bağımsız değişkene hangi oranda bağlı olduğunu göstermek maksadıyla regresyon analizi yapılmıştır.

Tablo 3. Güven, Adalet ve Yönetici Desteği Arasındaki Regresyon Analizi

\begin{tabular}{l|llllll}
$\begin{array}{l}\text { Bağımlı } \\
\text { Değişken }\end{array}$ & \multicolumn{1}{c}{$\mathbf{R}^{2}$} & Bağımsız Değişken & B & Beta & t & $\mathbf{p}$ \\
\multirow{2}{*}{ Örgütsel Güven } & \multirow{2}{*}{0,745} & Örgütsel Adalet & 0,127 & 0,172 & 4,102 & 0,000 \\
\cline { 3 - 6 } & & Yönetici Desteği & 0,411 & 0,717 & 17,149 & 0,000
\end{tabular}

Tablo 3'te yer alan doğrusal regresyon sonuçlarına göre “örgütsel adalet”, “yönetici desteği” değişkenlerinin “örgütsel güven” değişkeni üzerinde istatistiksel olarak anlamlı $(\mathrm{p}<0,001)$ etkisi bulunmaktadır.

Örgütsel adalet ve yönetici desteği değişkenlerinin örgütsel güven değişkenini açıklama düzeyi $\left(\mathrm{R}^{2}=0,649\right)$ olarak tespit edilmiştir.

Tablo 3.'teki $\mathrm{R}^{2}$ sütunundaki değerlerden “örgütsel adalet” ve “yönetici desteği”, bağımlı değişken duru mundaki "örgütsel güven” değişkenine ait varyansı \% 75 oranında açıkladığ 1 , diğer bir ifadeyle çalışanların örgütsel güven algıların ın \% 75 oranında adalet ve yönetici desteği algılarına bağlı olarak şekillendiğ i anlaşılmaktadır. Dolayısıyla araştırmannın ikinci hipotezi $\left(\mathrm{H}_{2}\right)$ de kabul edilmiştir.

Bazı demografik değişkenlere ilişkin analiz sonuçları aşağıda ifade edilmiştir.

- Çalışan algıların ın yaşlarına göre farklılaşıp farklılaşmadığı incelendiğ inde; adalet algısı için $\mathrm{F}=11,695$ $\mathrm{p}<0,05$, yönetici desteği algıs 1 için $F=6,339 \mathrm{p}<0,05$ ve güven algıs 1 için $F=4,316 \mathrm{p}<0,05$ olduğu görülmüştür. Buna göre çalışanların adalet, yönetici desteği ve güven algıları ile yaş değişkeni arasında istatistiksel olarak (0,05 önem seviyesinde) anlamlı bir fark olduğu tespit edilmiştir. Çalışanların adalet, yönetici desteği ve güven algıları ortalamaların ın en yüksek olduğu yaş aralığın ın 50 yaş ve üzeri olduğu görülmektedir. Çalışanların adalet, yönetici desteği ve güven algıları ortalamaların ın en düşük olduğu yaş aralığının ise 20-30 yaşları arasında olduğu görülmektedir.

- Çalışan algılarının cinsiyetlerine göre farklılaşıp farklılaşmadı̆̆ incelendiğ inde; adalet alg $1 \mathrm{~S} 1$ iç in $\mathrm{t}=1,718$ $\mathrm{p}>0,05$, yönetici desteği alg1sı iç in $\mathrm{t}=1,821 \mathrm{p}>0,05$ ve güven $\operatorname{alg} 1 \mathrm{~s} 1$ iç in $t=1,527 \mathrm{p}>0,05$ olduğu görülmüştür. Buna göre çalışanların adalet, yönetici desteği ve güven algıları ile cinsiyet değişkeni arasında istatistiksel 
olarak (0,05 önem seviyesinde) anlamlı bir farklılaş ma görülmemektedir. Erkeklerin adalet, yönetici desteği ve güven algıları ortalamalarının bayanlardan daha yüksek olduğu görülmüştür.

- Çalışan algılarının medeni durumlarına göre farklılaşıp farklılaşmadığı incelendiğinde; adalet algıSı için

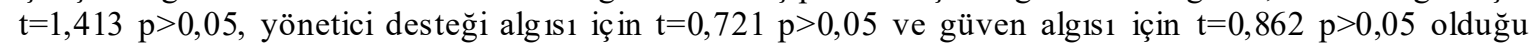
görülmüştür. Buna göre çalışanların adalet, yönetici desteği ve güven algıları ile medeni durumları arasında istatistiksel olarak (0,05 önem seviyesinde) anlamlı bir farklılaşma görülmemektedir. Evlilerin adalet, yönetici desteği ve güven düzeylerinin bekârların düzeylerinden daha yüksek düzeyde olduğu görülmektedir.

- Çalışan algıların ın eğitim seviyelerine göre farklılaşıp farklılaş madığ 1 incelendiğinde; adalet a $\lg ı \mathbf{S} 1$ için $\mathrm{F}=3,827 \mathrm{p}<0,05$, yönetici desteği için $\mathrm{F}=2,406 \mathrm{p}>0,05$ ve güven $\operatorname{alg} 1 \mathrm{~s} 1$ için $\mathrm{F}=3,649 \mathrm{p}>0,05$ olduğu görülmüştür. Buna göre çalışanların adalet algıları ile eğitim durumları arasında istatistiksel olarak anla mlı bir farklılaşma görülürken, yönetici desteği ve güven algıları ile eğitim durumları arasında istatistiksel olarak (0,05 önem seviyesinde) anlamlı bir farklılaş ma görülmemektedir. Lisansüstü mezunlarının adalet, yönetici desteği ve güven düzeyleri ortala mas ın in ilköğretim, lise ve üniversite me zunları ortalamalarından yüksek olduğu, lise mezunların nn adalet, yönetici desteği ve güven düzeyleri ortalamasının ise ilköğretim, üniversite ve lisansüstü mezunlarının ortalamalarından düşük olduğu görülmektedir.

- Çalışan alg llarının iş tecrübelerine göre farklılaşıp farklılaş madığı incelendiğinde; adalet alg 1 S 1 iç in $\mathrm{F}=3,818$ $p<0,05$, yönetici desteği için $F=1,989 p>0,05$ ve güven algısı için $F=2,029 p>0,05$ olduğu görülmüştür. Buna göre adalet algıları ile iş tecrübeleri arasında istatistiksel olarak anlamlı b ir farklılaşma görülürken, yönetici desteği ve güven algıları ile iş tecrübeleri arasında istatistiksel olarak $(0,05$ önem seviyesinde) anlamlı bir farklılaşma görülmemektedir. Buna göre; 20 yıl ve üzeri çalışanların adalet, yönetici desteği ve güven düzeyleri ortalamasının daha az yıl çalışanların ortalamalarından yüksek olduğu, 1-5 yıl arası çalışanların yönetici desteği ve güven düzeyleri ortalamasın in ise 5 yıl ve üzeri çalışanların ortalamalarından düşük olduğu görülmektedir.

\section{Sonuç}

Çalış mada, örgütsel adalet ve yönetici desteği algısın ın, örgütsel güven algısı üzerindeki etkisi araştırılmıştır. Araştırma sonucunda araştırma problemini destekleyen sonuçlar elde edilmiştir. Araştırmada yapılan testler ve analizler kapsamında elde edilen sonuçlar aşağıda belirtilmiştir.

Yapılan araştırmada da Tablo 2 ve 3’te görüldüğü gibi örgütsel adalet, yönetici desteği ve örgütsel güven arasındaki iliş kilerin istatistiki olarak anlamlı olduğu sonuçları elde edilmiştir. Yapılan an alizde ikili değişken ler arasındaki ilişki gücünü (derecesini) gösteren korelasyon katsayısının anlamlılığın ın yüksek olduğu başka bir deyişle değişkenler arasında pozitif yönlü yüks ek düzeyde bir iliş ki bulunduğu sonucuna ulaşılmıştır.

Ça lış mada kavramların birb irine olan etkisi incelendiğinde ise örgütsel adalet, yönetici desteği değişkenlerinin, örgütsel güven değişkeni üzerinde istatistiksel olarak anlamlı bir etkiye sahip olduğu yapılan regresyon analiziyle görülmüştür.

Bu sonuçlar ile kavramların birbirleriyle arasındaki ilişkileri inceleyen çalış malar karşılaştırıldığında sonuçların birbirini desteklediği görülmüş ve çalışmanın iki hipotezi de kabul edilmiştir.

Çalışmada değişkenler arasındaki ikili ilişkiler incelendiğinde;

Çalı̧̧anların yönetici desteği algıları ile adalet algıları arasında pozitif bir ilişki olduğu görülmüş, bu durumun adalet algısının, yönetici desteği algısı üzerindeki güçlü etkisinden kaynaklandığı varsayılmıştır. Çalışanlara karşı gösterilen adil davranışlar, çalışanların yöneticilerinden memnuniyet duymalarını sağlamaktadır. Böylece de yönetici desteği algıları olumlu anlamda pekişmektedir. Bunu destekleyici olarak Alexander ve Ruderman (1987), yaptıkları çalışmada çalışanların dağıtımsal ve prosedürel adalete yönelik algıların in, üst düzey yöneticilere duyulan güvene etki ettiğini belirtmiştir.

Ça lişanların güven alg 1ları ile adalet alg 1 ları arasında pozitif bir ilişki o lduğu görülmüş, bu durumun çalışanların güven algıların ın oluşumunda adalet kavramının temel bir yapıtaşı olmasından ileri geldiğ $i$ söylenebilir. Alexander ve Ruderman (1987), prosedürel ve dağıtımsal adalete ilişkin algılamaların, üst düzey yöneticilere duyulan güveni belirlediğini ifade etmişlerdir. Folger ve Konovsky (1989), yöneticilerin adil prosedürlere dayanan uygulamalarının, insan kaynaklarının sisteme ve yöneticilerine güvenmeleri sonucunu doğuracağını belirtmiştir (İşbaş1, 2000: 82-83; Özler, 2010: 48-49).

Çalışanların güven algıları ile yönetici desteği algıları arasında pozitif bir ilişki olduğu görülmüş ayrıca çalış mada değişkenler arasında ikili olarak incelenen ilişkilerdeki korelasyon katsayıları açısından en yüksek 
katsayının 0.858 ile güven algısı ve yönetici desteği algısı değişkenleri arasında olduğu görülmüştür. Bunun nedenini anlayabilmek ad ına yönetici desteği tanımla ma ların 1 incelediğ imizde yönetici desteği öğelerinin; güven, saygı ve yöneticin in çalışana yardım etme konusundaki isteklilik olmak üzere üç unsurdan oluştuğu görülecektir (Gagnon ve Michael, 2004; Giray, 2013: 73).

$\mathrm{Bu}$ çalışmanın bazı Güneydoğu illeriyle sınırlı kalması, sınırlı sayıda anket uygulanmış olması, araştırma kapsamına alınan işletmelerin zaman ve mekân kısıtlamaları temel kısıtlardan sayılabilir. Ayrıca adalet, yönetici desteği ve güven gibi kavramların değerlendirmesinin diğer anket çalışmalarında olduğu gibi objektif değerlemelerden ziyade çalışanların alg ısına dayanması ve literatür kavramlarında belli bir mutabakatın oluşmamış olması diğer bir kısıttır.

Havacılık sektöründe uygulanan bu çalışmayla bu alanda faaliyet gösteren işletme ve yöneticilere üzerinde dikkatlice durmaları gereken bazı öneriler sunulmuştur. Bu öneriler şöyle özetlenebilir;

Havacılık sektörü düşünüldüğünde müşterilere daha kaliteli hizmet sunabilmek rekabet şartlarında önemli hale geldiğinden, örgütsel güvenin arttırılması ile çalışanlar, müşteriler ile daha iyi ilişkiler kurabilecektir. Bu durum ise örgüt çıkarları ile çalışan çıkarlarının ortak noktalarda buluşması ile oluşabilecek bir durumdur. Müşterilerden (memnuniyet anketleriyle) alınan geri dönüşümler, çalışanların performanslarıyla kıyaslanabileceğ gibi çalışanların a lacakları ödül, prim, ikramiye gibi ücretlerde bu kapsamda örgütsel güvenin sağlanması adına değerlendirilebilir. Ancak örgütlerde ça lışanların gerek gayretlerinin karşılıkların 1 almalarında gerekse performansların 1 arttırabilmelerinde örgüt tarafından sağlanan maddi imkânlar kadar bu imkânların adil bir şekilde uygulanmasın in da çalışanlara güven vereceği unutulmamalıdır. Ayrıca çalışanların kararla ra katılımı sağlanarak, kendilerine değer verildiği gösterilmelidir. Çalışanlardan habersiz alınan kararların adaletsizlik oluşturacağ́ düşünüldüğünde, yöneticiler ve çalışanlar arasında kurulan sağlıklı ilet işimin güven oluşturacağ açıktır. Öncelikle yöneticilerin, işyerindeki astlarının verim ve etkinliklerini en üst düzeye çıkarılabilmelerinin ancak onların güven düzeylerini artırmakla olabileceğini bilmeleri gerekir. Bu kapsamda havacılık işletme ve yöneticilerinin, örgüt çalş̧anlarına adil bir işyeri atmosferi sunmaları gerektiği böyle olması durumunda çalışanlarının örgütlerine olan güvenlerini olumlu yönde etkileyeceğini göz önünde bulundurmaları gerekir. Adaletli bir örgüt havası oluşturmayı başarabilen yöneticiler, bunu uzun vadeli bir politika ve strateji haline getirmelidir. Adalet algısıyla aradığı güven ortamına kavuşan çalışanların daha uzun süre örgüt üyeliklerini devam ettirecekleri ve bu üyeliği de gönüllü olarak sürdürecekleri açıktır. Bunun sonucunda da çalışan performansındaki artış, örgüt verimliliğine doğrudan yansıyacaktır.

\section{Kaynakça}

Aksoy, C. (2012). Insan Kaynakları Yönetiminde Örgütsel Bağlılı̆̆ın Belirleyicisi Olarak; Çalışanların Adalet Algıları Açısından Güven Faktörünün Incelenmesine Yönelik Bir Araştırma. Yüksek Lisans Tezi. Diyarbakır: DÜ. Sosyal Bilimler Enstitüsü.

Aktaş, E. (2010). Performans Değerlendirme Sistemlerinin Örgütsel Adalet Algısl Üzerine Etkisi. Yüksek Lisans Tezi. İzmir: DEÜ. Sosyal Bilimler Enstitüsü.

Alexander, S. ve Ruderman. M. (1987). The Role of Procedural and Distributive Justice in Organizational Behavior. Social Justice Research, 1, 177-198.

Aryee, S. A., Budhwar, P. ve Chen, Z. (2002) Trust As a Mediator of the Relationship Between Organizational Justice and Organizational Outcomes: Test of a Social Exchange Model. Journal of Organizational Behavior, 23, (3), 267-285.

Asunakutlu, T. (2001). Klasik ve Neo-Klasik Dönemde Örgütsel Güvenin Karşılaştırılması Üzerine Bir Deneme, Muğla Üniversitesi Sosyal Bilimler Enstitüsü Dergisi, Bahar 2001, Say1 5.

Babin, B. J. ve Boles, J. S. (1996). The Effects of Perceived Co-Worker Involvement and Supervisor Support on Service Provider Role Stress, Performance and Job Satisfaction. Journal of Retailing, 72 (1), 57-75.

Bhanthumnavin, D. (2000). Importance of Supervisory Social Support and Its Implications For HRD in Thailand. Psychology and Developing Societies, 12, 155-166.

Bhanthumnavin D. (2003). Perceived Social Support From Supervisor and Group Members' Psychological and Situational Characteristics As Predictors of Subordinate Performance in Thai Work Units. Human Resource Development Quarterly, 14, 74-97.

Burke, M. J., Borucki, C. C. ve Hurley, A. E. (1992). Reconceptualizing Psychological Climate in a Retail Service Environment: A Multiple Stakeholder Perspective. Journal of Applied Psychology, 77 (5), 717-729. 
Cohen-Charash, Y. ve Spector, P. E. (2001). The Rol of Justice in Organizations: A Meta-Analysis, Organizational Behavior and Human Decision Process, Volume 86, No 2.

Çakmak K. Ö. (2005). Performans Değerlendirme Sistemlerinde Örgütsel Adalet Algisl ve Bir Örnek Olay Çalışması, İstanbulÜniversitesi, Sosyal Bilimler Enstitüsü, Yüksek Lisans Tezi, İstanbul.

DeConinck, J. B. (2010). The Effect of Organizational Justice, Perceived Organizational Support, an d Perceived Supervisor Support on Marketing Employees' Level of Trust. Journal of Business Research, 63, 1349-1355.

Demircan, N. ve Ceylan, A. (2003). Örgütsel Güven Kavramı: Nedenleri ve Sonuçlar. Celal Bayar Üniversitesi, İktisadi ve İdari Bilimler Fakültesi, Yönetim ve Ekonomi Dergisi. 10, 2.

Fields, D. L. (2002). Taking The Measure of The Work, Sage Publication, London.

Folger, R. ve Cropanzono R. (1998). Organizational Justice and Human Resource Management, Sage Publications, London.

Folger, R. ve Konuvsky, M. A. (1989). Effects of Procedural and Distributive Justice On Reavtion To Pay Raise Decisions, Academy of Management Journal, 32 (1).

Frazier, M. L., Johnson, P. D., Gavin, M., Gooty, J. ve Snow, B. D. (2010). Organizational Justice, Trustworthiness and Trust: a Multifoci Examination. Group and Organization Management, 35, (1), 39-76.

Gagnon, M. A. ve Michael, J. H. (2004). Outcomes of Perceived Supervisor Support For Wood Production Employees. Forest Products Journal, 54, 172-177.

Giray, M. D. (2013). İş Yeri Desteği: Örgüt, Yönetici ve Çalışma Arkadaşları Desteğine Genel Bir Bakış. İş, Güç Endüstri İlişkileri ve İnsan Kaynakları Dergisi, 15 (3).

Greenberg, J. (1990). Organizational Justice: Yesterday, Today and Tomorrow. Journal of Management, 16 (2).

İşbaşı, J. (2000). Çalışanların Yöneticilere Duydukları Güvenin ve Örgütsel Adalete İlişkin Algılamalarının Örgütsel Vatandaşlık Davranışının Oluşumundaki Rolü: Bir Turizm Örgütünde Uygulama. Yayımlanmamış Yüksek Lisans Tezi. Antalya: AÜ. Sosyal Bilimler Enstitüsü.

Mishra, J., Morrissey, M.A. (1990). Trust in Employee/Employer Relationships: A Survey of West Michigan Managers, Public Personnel Managment, Volume 19, No 4.

Molla, G. (2011). Çalışanların Elektronik İnsan Kaynakları Yönetimi Uygulamalarına Ait Tutumları ile Örgütsel Güven Ölçeklerine Yönelik İlaç Sektöründe Bir Uygulama, Yüksek Lisans Tezi. İstanbul: YTÜ. Sosyal Bilimler Enstitüsü.

Niehoff, B. P. ve Moorman, R. H. (1993). Justice as a Mediator of the Relationship Between Methods of Monitoring and Organizational Citizenship Behavior, Academy of Management Journal, 36 (3), 527-556.

Nyhan, R. ve Marlowe, H. A. (1997). Development and Psychometric Proparties of the Organizational Trust Inventory, Evaluation Review, Volume 21, No 5.

Oldham, G. R. ve Cummings, A. (1996). Employee creativity: Personel and Contextual Factors at Work. Academy of Management Journal, 39 (3), 607-634.

Özler, D. E. (2010). Örgütsel Davranışta Güncel Konular. Bursa: Ekin Basım Yayın Dağıtım.

Polat, S. (2007). Ortaögretim Öğretmenlerinin Örgütsel Adalet Algllarl, Örgütsel Güven Düzeyleri İle Örgütsel Vatandaşlık Davranışları Arasındaki İlişki, Kocaeli Üniversitesi Sosyal Bilimler Enstitüsü, Yayımlanmamış Doktora Tezi, Kocaeli.

Powell, T. C. (2011). Behaviour Strategy. Journal of Strategic Management, 32 (13) 1369-1366.

Schminke, M., Ambrose, M. L. ve Cropanzano, R. S. (2000). The Effect of Organizational Structure on Perceptions of Procedural Fairness, Journal of Applied Psychology, Volume 85, No 2.

Stinglhamber, F., De Cremer, D. ve Mercken, L. (2006). Perceived Support as a Mediator of the Relationship Between Justice and Trust A Multiple Foci Approach. Group and Organization Management, 31, (4), 442-468.

Straiter, K. L. (2005). The Effects of Supervisors Trust of Subordinates and Their Organization on Job Satisfaction and Organizational Commitment. International Journal ofLeadership Studies, $1,1$.

Tan, H. H. ve Lim, A. (2009), Trust in Coworkers and Trust in Organizations, The Journal of Psychology, Volume 143, No 1.

Taylor, R. G. (1989), The Role of Trust In Labor Management Relations, Organization Development Journal, No 7.

Tongur, A. (2011). Organizational Support, Organizational Citizenship Behavior, and Perceived Performance in Crime Scene Investigation Units of Turkish National Police. Unpublished Dis sertation. Orlando. 
Wahlstrom, K. L. ve Louis, K. S. (2008). How Teachers Experience Principal Leadership: The Roles of Professional Community, Trust, Efficacy and Shared Responsibility, Educational Administration Quarterly, Volume 44, No 4.

Yilmaz, A. ve Atalay, C. G. (2009). A Theoretical Analyze On The Concept of Trust In Organisational Life, European Journal of Social Sciences, Volume 8, No 2.

Yoon, J. ve Lim, J. C. (1999). Organizational Support in the Workplace: The Case of Korean Hospital Employees. Human Relations, 52, 923-945.

Zaheer, A., McEviley B. ve Perrone V. (1998). Does Trust Matter? Exploring The Effects Interorganizational and Interpersonel Trust, On Performance, Organization Science, No 9.

Zaitouni, M. ve Nassar M. (2015). Perceived Supervisor Support as a Mediator between Organizational Justice and Trust in Supervisor: Evidence from Kuwaiti Banks. International Review of Business Research Papers, 11 (2), $170-188$. 